\title{
KONTAMINASI AWAL DAN DEKONTAMINASI BAKTERI PATOGEN PADA JEROAN SAPI DENGAN IRADIASI GAMMA
}

\author{
Harsojo, Irawati Z. \\ Pusat Aplikasi Isotop dan Radiasi, Batan \\ Jl. Lebak Bulus Batan Ps. Jumat, Jakarta Selatan 12240 \\ e-mail : apu.harsojo@yahoo.com
}

Diterima 13 Desember 2010, diterima dalam bentuk perbaikan 15 Maret 2011, disetujui 31 Maret 2011

\begin{abstract}
ABSTRAK
KONTAMINASI AWAL DAN DEKONTAMINASI BAKTERI PATOGEN PADA JEROAN SAPI DENGAN IRADIASI

GAMMA. Telah dilakukan penelitian mengenai kontaminasi awal serta dekontaminasi bakteri patogen dengan iradiasi gamma pada jeroan sapi seperti hati, babat dan paru. Bakteri patogen yang digunakan adalah Salmonella typhimurium, Escherichia coli 0157, Escherichia coli polyvalen dan Vibrio cholerae yang diinokulasikan ke dalam jeroan sapi. Parameter yang diukur adalah jumlah total bakteri aerob, total bakteri koli, E. coli, Staphylococcus spp dan isolasi Salmonella. Pada perlakuan dekontaminasi bakteri patogen, parameter yang diukur adalah jumlah koloni bakteri yang masih hidup setelah diiradiasi pada dosis 0; 0,1; 0,2; 0,3 dan 0,4 kGy di IRPASENA dengan laju dosis $1,149 \mathrm{kGy} / j \mathrm{jam}$. Hasil penelitian menunjukkan kontaminasi awal total bakteri aerob pada jeroan sapi berkisar antara $8,85 \times 10^{5}$ dan 1,08 $\times 10^{8} \mathrm{cfu} / \mathrm{g}$, sedangkan bakteri koli berkisar antara $2,70 \times 10^{6}$ dan 3,23 $\times 10^{7} \mathrm{cfu} / \mathrm{g}$. Total bakteri E. coli berkisar antara $8,55 \times 10^{5}$ dan 2,60 $\times 10^{7} \mathrm{cfu} /$ g. Sedangkan total Staphylococcus spp berkisar antara 1,6 $\times 10^{5}$ dan $4,10 \times 10^{7} \mathrm{cfu} / \mathrm{g}$. Tidak ditemukan Salmonella pada semua contoh yang diteliti, akan tetapi E. coli ditemukan pada semua contoh yang diteliti. Pada jeroan sapi, bakteri E. coli 0157 merupakan bakteri yang paling peka terhadap iradiasi, sedangkan V. cholerae merupakan bakteri yang paling tahan terhadap iradiasi.
\end{abstract}

Kata kunci: Iradiasi, jeroan sapi, bakteri patogen, kontaminasi awal.

\begin{abstract}
INITIAL CONTAMINATION AND DECONTAMINATION OF SOME PATHOGENIC BACTERIA ON BEEF BOWEL BY GAMMA IRRADIATION. An experiment has been conducted to study the initial bacterial contamination and decontamination of pathogenic bacteria on beef bowel such as beef liver, tripe and lung by gamma irradiation. The measured paramater were the amount of total aerob bacteria, total coliforms, Escherichia coli, Staphylococcus spp. and identification of Salmonella. Another experiment has been conducted to study the effect of irradiation on some pathogenic bacteria which was inoculated on beef bowel. The bacteria included Salmonella typhimurium, E. coli 0157, E. coli polyvalen and Vibrio cholerae were inoculated on beef bowel, respectively. Irradiation was done with dose of 0; $0.1 ; 0.2 ; 0.3$ and $0.4 \mathrm{kGy}$. The irradiation was done at a Multipurpose Panoramic Batch Irradiatior (IRPASENA) with a dose rate of $1.149 \mathrm{kGy} / \mathrm{h}$. The results showed no Salmonella was detected in all samples observed. On the other hand, E. coli was found in all samples. The initial contamination of aerob bacteria were varied from 8.85 $\times 10^{5}$ to $1.08 \times 10^{8} \mathrm{cfu} / \mathrm{g}$ while coliform were varied from $2.70 \times 10^{6}$ to $3.23 \times 10^{7} \mathrm{cfu} / \mathrm{g}$. The total $\mathrm{E}$. coli were varied from $8.55 \times 10^{5}$ to $2.60 \times 10^{7} \mathrm{cfu} / \mathrm{g}$, while the total Staphylococcus spp were varied from $1.6 \times 10^{5}$ to $4.10 \times 10^{7} \mathrm{cfu} / \mathrm{g}$. E. coli 0157 was the most radiosensitive bacteria in beef bowel among others, likewise V. cholerae was the most radioresistant bacteria among the others.
\end{abstract}

Keywords: Irradiation, beef bowel, pathogenic bacteria, initial contamination.

\section{PENDAHULUAN}

$\mathrm{M}^{\mathrm{s}-\mathrm{man}}$ akanan adalah salah satu kebutuhan pokok manusia disamping kebutuhan primer lainnya. Berbagai komponen nutrisi dan gizi terkandung dalam makanan seperti karbohidrat, protein, lemak, vitamin, mineral dan zat-zat kimia lainnya dibutuhkan untuk memperbaiki jaringan tubuh yang rusak, mengatur proses di dalam tu- 
buh, perkembangan biakan dan menghasilkan energi untuk kepentingan berbagai kegiatan ${ }^{(1,2)}$. Di samping itu, makanan juga merupakan substrat yang cocok untuk pertumbuhan dan perkembangbiakan mikroba. Bila mikroba mengadakan kontak dengan makanan maka akan memungkinkan mikroba tumbuh dan berkembang biak.

Populasi mikroba yang terdapat dalam makanan beragam jenis dan jumlahnya. Hal ini disebabkan oleh adanya pengaruh selektif terhadap jumlah dan jenis mikroba awal yang ada pada makanan. Sumber-sumber mikroflora dapat berasal dari tanah, air permukaan, kotoran hewan atau manusia dan sumber lainnya. Pada makanan olahan, jumlah dan jenis bakteri yang dominan dipengaruhi oleh proses pengolahan atau pengawetan yang diterapkan pada makanan tersebut ${ }^{(1)}$. Awal kontaminasi pada daging atau jeroan berasal dari mikroorganisme yang memasuki peredaran darah pada saat penyembelihan dan bila ada alat-alat yang dipergunakan untuk pengeluaran darah tidak steril. Kontaminasi berikutnya dapat terjadi pada saat persiapan daging seperti proses pembelahan karkas, pendinginan, pembekuan, penyegaran daging beku, pemotongan karkas atau daging, pembuatan produk daging proses, pengeluaran jeroan, pengawetan, pengepakan, penyimpanan dan distribusi ${ }^{(3)}$.

Jeroan merupakan salah satu produk samping yang dihasilkan dari kegiatan pemotongan di rumah potong. Disamping itu, jeroan merupakan sasaran kontaminasi oleh beberapa mikroba yang mempercepat kerusakan jeroan sehingga tidak layak dikonsumsi. Di Indonesia masyarakat banyak mengkonsumsi jeroan karena harganya yang relatif lebih murah daripada daging, walaupun kandungan gizinya lebih rendah dibandingkan dengan daging. Di luar negeri seperti Amerika, Eropa dan lain-lain jeroan tidak dikonsumsi oleh manusia akan tetapi diolah kembali menjadi pakan ternak.

Salah satu bakteri yang berbahaya selain Salmonella adalah E. coli 0157:H7. Bakteri ini dapat menyebabkan hemorrhagic colitis yang banyak dijumpai pada air yang terkontaminasi oleh kotoran manusia. Bakteri ini memproduksi toksin hemorrhagic colitis sehingga jeroan akan mudah terkontaminasi bakteri ini ${ }^{(4)}$.

Tujuan penelitian ini untuk mempelajari kontaminasi awal mikroba pada jeroan sapi serta dekontaminasi bakteri patogen dengan menggunakan iradiasi gamma.

\section{METODOLOGI}

\section{Bahan}

Bahan yang digunakan dalam penelitian ini ialah jeroan sapi berupa hati, babat, dan paru yang dibeli dari beberapa pasar swalayan dan tradisional, masing-masing pasar sebanyak 5 tempat. Bakteri yang digunakan sebagai inokulan adalah S. typhimurium, E. coli $0157, E$. coli polyvalen dan V. cholerae yang berasal dari koleksi laboratorium mikrobiologi (PAIRCC).

\section{Penentuan Jumlah Total Bakteri Aerob, Bakteri Koli, dan Staphylococcus spp. Pada Jeroan Sapi}

Penentuan jumlah total bakteri aerob, bakteri koli, dan Staphylococcus spp. pada jeroan sapi, dilakukan dengan cara menimbang jeroan sapi seberat $25 \mathrm{~g}$ per contoh. Kemudian contoh dicampur dengan air pepton steril $(225 \mathrm{ml})$ yang disebut sebagai larutan suspensi. Terhadap larutan suspensi dilakukan pengenceran bertingkat. Sebanyak 0,1 ml larutan suspensi ditanam pada media lempeng cawan petri yang berisi agar nutrien (Oxoid) untuk penentuan jumlah total bakteri aerob, sedang untuk penentuan jumlah bakteri koli, dan Staphylococcus spp. masing-masing ditanam pada media Mac Conkey dan media Baird Parker (0xoid). Pengeraman dilakukan pada suhu kamar untuk jumlah bakteri aerob, sedang untuk bakteri koli dan Staphylococcus spp. disimpan pada suhu $37^{\circ} \mathrm{C}$. selama $24-48$ jam untuk selanjutnya dihitung jumlah koloni bakteri yang tumbuh.

\section{Penentuan Jumlah Bakteri E. coli}

Penentuan jumlah bakteri E. coli dilakukan dengan menggunakan media EMB (Oxoid) menurut metode Fardiaz ${ }^{(5)}$. Penentuan dugaan $E$. coli ini yang salah satu bagian bakteri koli, digunakan sebagai penentu untuk bakteri koli.

\section{Penentuan Jumlah Salmonella}


Pemeriksaan Salmonella dilakukan dengan cara menimbang contoh sebanyak $10 \mathrm{~g}$ kemudian ditanam dalam media pengaya dan disimpan pada suhu $37^{\circ} \mathrm{C}$ selama 24 jam dan selanjutnya ditanam dalam media selektif (XLD) yang disimpan pada suhu $37^{\circ} \mathrm{C}$ selama 48 jam. Koloni yang tumbuh diidentifikasi secara mikrobiologi dan biokimia ke arah Salmonella dan dilanjutkan dengan uji serologi untuk ditentukan serotipe, seperti prosedur yang dilakukan oleh ANDINI dkk. ${ }^{(6)}$

\section{Tata Kerja Resistensi Bakteri}

Bakteri yang akan digunakan diremajakan terlebih dahulu dalam media agar nutrien miring kemudian diinkubasi selama 24 jam pada suhu $37^{\circ} \mathrm{C}$. Selanjutnya dibuat suspensi dengan konsentrasi kekeruhan $3 \times 10^{8}$ $\mathrm{sel} / \mathrm{ml}$. Sebanyak $10 \mathrm{~g}$ contoh dimasukkan ke dalam kantong plastik, ditutup rapat dan kemudian diiradiasi steril yang tergantung dari kontaminasi awal. Kemudian masing-masing contoh diinokulasi dengan suspensi bakteri yang dicobakan. Selanjutnya contoh diiradiasi dengan dosis $0 ; 0,1 ; 0,2 ; 0,3$; dan 0,4 kGy pada laju dosis 1,149 $\mathrm{kGy} / \mathrm{jam}$. Contoh yang telah diiradiasi diencerkan bertingkat dan selanjutnya ditanam pada media agar Nutrien kemudian diinkubasi pada suhu $37^{\circ} \mathrm{C}$ selama $24-48$ jam.

\section{Penetuan Nilai $D_{10}$}

Nilai $D_{10}$ ditentukan dengan cara membuat grafik jumlah bakteri pada sumbu $Y$ dan dosis iradiasi pada sumbu X seperti metode Rashid et al.dan Ito et al. ${ }^{(7,8)}$

\section{HASIL DAN PEMBAHASAN}

Pada Tabel 1 dapat dilihat kontaminasi awal bakteri aerob pada jeroan sapi berupa hati, babat dan paru yang sering dikonsumsi oleh masyarakat Indonesia. Jeroan tersebut di beli dari 2 macam pasar yaitu pasar swalayan dan tradisional di Jakarta. Secara umum terlihat bahwa kontaminasi awal bakteri aerob pada jeroan sapi di pasar swalayan lebih tinggi dibandingkan dengan pasar tradisional. Di pasar swalayan kontaminasi bakteri aerob tertinggi didapatkan pada hati sapi sebesar $1,08 \times 10^{8} \mathrm{cfu} / \mathrm{g}$ kemudian diikuti dengan paru dan babat. Sedangkan di pasar tradisional kontaminasi tertinggi didapatkan pada paru yaitu sebesar 7,60 $\times 10^{5}$ $c f u / g$, kemudian hati dan babat. Tingginya kontaminasi bakteri aerob di pasar swalayan kemungkinan disebabkan jeroan yang dijual belum tentu habis terjual pada hari yang sama dan udara yang berputar di pasar swalayan tidak sebaik di pasar tradisional walaupun di pasar swalayan menggunakan ruang yang mempunyai alat pendingin. Dengan demikian tidak ada jaminan bahwa jeroan yang dijual di pasar swalayan mutunya akan lebih baik dibandingkan pada pasar tradisional. Kemungkinan lain di pasar swalayan belum menerapkan Sistem Manajemen Keamanan Mutu. Di pasar tradisional kemungkinan jeroan yang dijual akan habis pada hari yang sama sehingga tidak ada lagi sisa jeroan yang harus disimpan untuk dijual keesokan harinya. Kemungkinan lain kontaminasi terjadi melalui pisau, telenan dan alat bantu lain yang digunakan. Sistim transportasi dan distribusi jeroan sapi dari tempat pemotongan ke tempat pengolahan juga memegang peranan penting.

Tabel 1. Kontaminasi awal bakteri aerob jeroan sapi yang berasal dari pasar swalayan dan tradisional.

\begin{tabular}{|c|c|c|}
\hline Lokasi Pasar & Contoh & Jumlah bakteri (cfu/g) \\
\hline \multirow{3}{*}{ Swalayan } & Hati & $1,08 \times 10^{8}$ \\
\cline { 2 - 3 } & Babat & $1,14 \times 10^{7}$ \\
\cline { 2 - 3 } & Paru & $1,56 \times 10^{7}$ \\
\hline \multirow{3}{*}{ Tradisional } & Hati & $1,25 \times 10^{6}$ \\
\cline { 2 - 3 } & Babat & $8,85 \times 10^{5}$ \\
\cline { 2 - 3 } & Paru & $7,60 \times 10^{6}$ \\
\hline
\end{tabular}

Pada penelitian ini juga dipelajari kontaminasi bakteri koli yang terdapat pada jeroan sapi yang dijual di Jakarta. Bakteri ini juga sering mengkontaminasi daging maupun jeroan yang disebabkan oleh penanganan secara tradisional pada saat pemotongan maupun pada saat diproses ${ }^{(9)}$. Kehadiran bakteri koli tersebut merupakan parameter ada tidaknya materi kotoran/fekal di dalam bahan tersebut dan sangat tidak diharapkan kehadirannya di dalam makanan. Bakteri koli merupakan bakteri indikator adanya polusi kotoran atau fekal. ${ }^{(2,10)}$ 
Penggunaan jasad indikator pada bahan makanan mempunyai keuntungan karena lebih tahan pada proses pengolahan dan selama proses penyimpanan ${ }^{(11)}$. Bakteri koli merupakan salah satu jenis bakteri yang digunakan sebagai indikator sanitasi ${ }^{(10)}$. Oleh karena itu, penerapan teknik deteksi bakteri koli di dalam bahan sangatlah penting karena dengan demikian dapat diketahui apakah bahan tersebut masih layak digunakan atau tidak. Beberapa strain bakteri koli seperti $E$. coli telah diketahui dapat menyebabkan diare pada bayi dan juga ditemukan pada anak-anak sapi yang menderita mastitis. Pada infeksi yang parah $E$. coli mungkin terdapat dalam darah, saluran kencing, appendix dan peritonium ${ }^{(12)}$. E. coli sebagai bakteri yang umum terdapat dalam saluran pencernaan dapat berkembang biak dan menjadi patogen dalam saluran reproduksi.

Nilai kontaminasi awal bakteri koli pada jeroan sapi disajikan pada Tabel 2. Pada Tabel tersebut terlihat kontaminasi bakteri koli yang didapatkan dari pasar swalayan lebih tinggi dibandingkan dengan pasar tradisional. Kontaminasi bakteri koli dari pasar swalayan tertinggi didapatkan pada hati sapi yaitu sebesar 3,23x $10^{7} \mathrm{cfu} / \mathrm{g}$, kemudian diikuti dengan paru dan babat. Kontaminasi bakteri koli tertinggi di pasar tradisional didapatkan pada paru yaitu $1,11 \times 10^{7} \mathrm{cfu} / \mathrm{g}$, kemudian diikuti dengan hati dan babat.

Tabel 2. Kontaminasi awal bakteri koli jeroan sapi yang berasal dari pasar swalayan dan tradisional.

\begin{tabular}{|c|c|c|}
\hline Lokasi Pasar & Contoh & Jumlah bakteri(cfu/g) \\
\hline \multirow{3}{*}{ Swalayan } & Hati & $3,23 \times 10^{7}$ \\
\cline { 2 - 3 } & Babat & $1,06 \times 10^{7}$ \\
\cline { 2 - 3 } & Paru & $1,40 \times 10^{7}$ \\
\hline \multirow{3}{*}{ Tradisional } & Hati & $7,00 \times 10^{6}$ \\
\cline { 2 - 3 } & Babat & $2,70 \times 10^{6}$ \\
\cline { 2 - 3 } & Paru & $1,11 \times 10^{7}$ \\
\hline
\end{tabular}

Kontaminasi awal bakteri E. coli pada jeroan disajikan pada Tabel 3. Pada Tabel 3 terlihat bahwa semua contoh yang diteliti terkontaminasi $E$. coli. Kontaminasi tertinggi di pasar swalayan didapatkan pada babat yaitu $2,60 \times 10^{7} \mathrm{cfu} / \mathrm{g}$, kemudian diikuti dengan paru dan hati. Sedang di pasar tradisional kontaminasi $E$. coli tertinggi didapatkan pada hati $\left(1,26 \times 10^{7} \mathrm{cfu} / \mathrm{g}\right)$, kemudian diikuti dengan babat dan paru. Kemungkinan terjadinya kontaminasi berasal dari alat-alat seperti pisau, telenan dan lain sebagainya yang digunakan untuk memotong jeroan akibat terjadi kontaminasi silang.

Tabel 3. Kontaminasi awal bakteri $E$. coli jeroan sapi yang berasal dari pasar swalayan dan tradisional.

\begin{tabular}{|c|c|c|}
\hline Lokasi Pasar & Contoh & Jumlah bakteri (cfu/g) \\
\hline \multirow{3}{*}{ Swalayan } & Hati & $8,55 \times 10^{5}$ \\
\cline { 2 - 3 } & Babat & $2,60 \times 10^{7}$ \\
\cline { 2 - 3 } & Paru & $1,95 \times 10^{6}$ \\
\hline \multirow{3}{*}{ Tradisional } & Hati & $1,26 \times 10^{7}$ \\
\cline { 2 - 3 } & Babat & $3,40 \times 10^{6}$ \\
\cline { 2 - 3 } & Paru & $1,65 \times 10^{6}$ \\
\hline
\end{tabular}

Tabel 4. Kontaminasi awal bakteri Staphylococcus spp. jeroan sapi yang berasal dari pasar swalayan dan tradisional.

\begin{tabular}{|c|c|c|}
\hline Lokasi Pasar & Contoh & Jumlah bakteri (cfu/g) \\
\hline \multirow{3}{*}{ Swalayan } & Hati & $4,10 \times 10^{7}$ \\
\cline { 2 - 3 } & Babat & $6,06 \times 10^{6}$ \\
\cline { 2 - 3 } & Paru & $9,60 \times 10^{6}$ \\
\hline \multirow{3}{*}{ Tradisional } & Hati & $9,85 \times 10^{6}$ \\
\cline { 2 - 3 } & Babat & $1,60 \times 10^{5}$ \\
\cline { 2 - 3 } & Paru & $8,20 \times 10^{5}$ \\
\hline
\end{tabular}


Meskipun E. coli pada jeroan sangat tidak diharapkan namun pada penelitian ini tidak dilakukan analisis lebih lanjut tentang patogenitas $E$. coli. Saat ini telah berkembang adanya $E$. coli yang patogen bagi manusia. Salah satu $E$. coli yang patogen adalah $E$. coli $0157: H 7$ yang diketahui dapat menyebabkan perdarahan dan pernah menghebohkan dunia. ${ }^{(13)}$ Menurut Ratih, ${ }^{(14)}$ kasus keracunan pangan dapat disebut seperti gunung es yang mungkin salah satu penyebabnya adalah dari bakteri koli. Mengingat hal ini untuk waktu yang akan datang analisis mengenai patogenitas $E$. coli sangat perlu dilakukan.

Tabel 4 menunjukkan kontaminasi awal bakteri Staphylococcus spp. jeroan sapi yang berasal dari 2 macam pasar. Terlihat bahwa kontaminasi Staphylococcus spp tertinggi ditemukan pada pasar swalayan dibandingkan dengan pasar tradisional. Jeroan di pasar swalayan yang paling tinggi kontaminasi Staphylococcus spp. terdapat pada hati yaitu $4,10 \times 10^{7} \mathrm{cfu} / \mathrm{g}$ kemudian diikuti dengan paru dan babat masing-masing se-

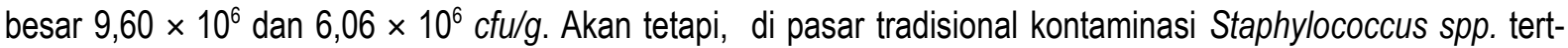
inggi didapatkan juga pada hati yaitu $9,85 \times 10^{6} \mathrm{cfu} / \mathrm{g}$ kemudian diikuti dengan paru dan babat dengan jumlah koloni masing-masing sebesar $8,20 \times 10^{5}$ dan 1,60 × 105 cfu/g.

Ditemukannya bakteri Staphylococcus spp pada semua contoh jeroan di pasar swalayan maupun tradisional menunjukkan bahwa penjual kurang memperhatikan kebersihan lingkungan sehingga jeroan yang dijual terkontaminasi Staphylococcus spp. Staphylococcus sp. menghasilkan racun sehingga menimbulkan intoksikasi dan paling banyak dilaporkan di Amerika Serikat. Menurut Supardi dan Sukamto, ${ }^{(2)}$ kejadian keracunan oleh Staphylococcus sp. di Amerika Serikat setiap tahunnya mencapai 20 sampai $30 \%$ dari seluruh keracunan makanan. Penyebab terjadinya keracunan adalah tertelannya toksin yang mungkin terdapat dalam makanan dan diproduksi oleh spesies dan strain tertentu dari bakteri Staphylococcus $s p$.

Bakteri dari genus Salmonella merupakan bakteri penyebab infeksi dan bila tertelan/masuk ke dalam tubuh akan menimbulkan gejala yang disebut salmonellosis. Menurut Mulder dan Bolder yang dikutip dari Sri Poernomo ${ }^{(15)}$. mikroba yang mempunyai pilli seperti Salmonella mempunyai kesanggupan untuk menempel pada permukaan karkas dan sekali menempel sukar untuk diangkat, walaupun dengan menambahkan bahan kimia ke dalam air yang dipergunakan untuk mencuci karkas. Kejadian Luar Biasa (KLB) yang disebabkan oleh Salmonella maupun Staphylococcus sp. di Indonesia belum banyak dilaporkan dan dapat disebut fenomena gunung es karena pangan dikonsumsi setidaknya tiga kali sehari ${ }^{(16,17)}$. Persentase jumlah yang dilaporkan masih terlalu kecil bila dibandingkan dengan wabah yang sebenarnya terjadi ${ }^{(18)}$. Menurut Jenie, ${ }^{(19)}$ letusan penyakit asal pangan yang terjadi di negara berkembang menyebabkan kematian 2,2 juta anak oleh penyakit diare. Penyebab diare adalah bakteri patogen berasal dari pangan maupun dari air. Salmonella merupakan salah satu bakteri yang disebarluaskan melalui makanan dan paling patogen dibandingkan dengan bakteri patogen lainnya ${ }^{(20)}$. Pada semua contoh jeroan yang diteliti tidak ditemukan adanya bakteri Salmonella. Walaupun demikian tidak berarti bahwa jeroan tersebut aman karena dari hasil kontaminasi awal diketahui pada semua jeroan yang dijual di pasar swalayan maupun tradisional telah terkontaminasi $E$. coli.

Nilai $D_{10}$ beberapa bakteri patogen disajikan pada Tabel 5 . Radioresistensi masing-masing bakteri dapat dilihat dari nilai $D_{10}$. Makin tinggi nilai $D_{10}$ suatu bakteri menunjukkan makin tahan bakteri tersebut terhadap iradiasi. Nilai ini dapat digunakan untuk menentukan keperluan dekontaminasi jeroan sapi yang tercemar oleh Salmonella atau bakteri lainnya seperti $E$. coli maupun V. cholerae. Kematian bakteri tersebut dalam jumlah besar dapat disebabkan oleh kemampuan sinar gamma yang sangat besar sebagai pengion dengan panjang gelombang pendek dan energi yang besar dapat mengakibatkan perubahan kimia dalam bakteri. Perubahan kimia tersebut adalah penghambat sintesis DNA yang mengakibatkan proses pembelahan sel dan reproduksi bakteri terganggu ${ }^{(21)}$.

Tabel 5. Nilai $D_{10}(k G y)$ beberapa bakteri patogen.

\begin{tabular}{|c|c|c|c|c|}
\hline \multirow{2}{*}{ Sampel } & \multicolumn{4}{|c|}{ Nilai $\mathrm{D}_{10}(\mathrm{kGy})$} \\
\cline { 2 - 5 } & S. typhimurium & E. coli 0157 & E. coli polyvalen & V. cholerae \\
\hline
\end{tabular}




\begin{tabular}{|c|c|c|c|c|}
\hline Hati & 0,33 & 0,16 & 0,32 & 0,71 \\
\hline Babat & 0,30 & 0,15 & 0,15 & 0,62 \\
\hline Paru & 0,18 & 0,15 & 0,15 & 0,48 \\
\hline
\end{tabular}

Nilai $D_{10}$ tertinggi didapatkan pada $V$. cholerae dengan contoh berupa hati yaitu $0,71 \mathrm{kGy}$ kemudian diikuti dengan babat dan paru masing-masing sebesar 0,62 dan 0,48 kGy. Selanjutnya nilai $D_{10}$ tertinggi setelah $V$. cholerae adalah $S$. typhimurium. Nilai $D_{10} S$. typhimurium bervariasi antara 0,18 dan $0,33 \mathrm{kGy}$, sedangkan nilai $D_{10}$ antara E. coli 0157 dan E. coli polyvalen tidak jauh berbeda pada babat dan paru. Akan tetapi, pada contoh hati nilai $D_{10} E$. coli polyvalen mencapai $0,32 \mathrm{kGy}$. Hasil penelitian Harsojo dkk ${ }^{(22)}$, menunjukkan adanya variasi nilai $D_{10}$ bakteri patogen mungkin disebabkan adanya perbedaan kepekaan jenis bakteri yang tumbuh pada substrat dan komposisi substrat itu sendiri. Hal ini terlihat pada nilai $D_{10}$ untuk $V$. cholerae yang diperoleh pada jeroan sapi lebih tinggi dibandingkan dengan S. typhimurium.

\section{KESIMPULAN}

Kontaminasi awal bakteri aerob, bakteri koli dan Staphylococcus tertinggi didapatkan pada contoh hati untuk pasar swalayan sedangkan untuk pasar tradisional kontaminasi awal tertinggi bakteri aerob dan bakteri koli didapatkan pada paru. Kontaminasi awal tertinggi untuk bakteri Staphylococcus didapatkan pada contoh hati. Pada semua contoh jeroan yang diteliti didapatkan telah terkontaminasi $E$. coli akan tetapi tidak ditemukan adanya kontaminasi Salmonella. $V$. cholerae merupakan bakteri yang paling tahan terhadap iradiasi dibandingkan dengan bakteri patogen lainnya, sedang E. coli 0157 lebih peka terhadap iradiasi dibandingkan dengan E. coli polyvalen.

\section{DAFTAR PUSTAKA}

1. K.K. UNI, Laporan akhir analisa logam berat organ hati ternak potong cara AAS, Lembaga Penelitian Universitas Padjadjaran, Fak MIPA, Bandung (1991) 1

2. I. SUPARDI dan SUKAMTO, "Mikrobiologi Dalam Pengolahan dan Keamanan Pangan", Penerbit Alumni, Bandung (1999)

3. SOEPARNO, "IImu dan Teknologi Daging", Gajah Mada University Press (1994)

4. B.SYAMSUL dan T.B. MURDIATI, "Tuntutan Keamanan dan Pengamanan Pangan (daging sapi) pada Era Globalisasi", Prosiding Seminar Nasional. Peternakan dan Veteriner, Bogor (1997) 96-107

5. S. FARDIAZ, Penuntun praktek mikrobiologi pangan IPB, Bogor (1989)

6. L.S. ANDINI, HARSOJO, S.D. ANASTASIA, dan M. MAHA, "Efek Iradiasi Gamma Pada Salmonella spp Yang Diisolasi Dari Ayam Segar", Risalah Pertemuan IImiah APISORA-BATAN, Jakarta (1995) 165-171

7. H.O. RASHID, H. ITO and I. ISHIGAKI, World J.of Microbiology and Biotechnology 8 (1992) 494-498

8. H. ITO, H., HARUN AI-RASHID, NARVEMON SANGTHONG, A.Y. PITAYA, R. PONGPEN, and I. ISHIGAKI, Radiat. Phys. Chem. 42 1-3 (1993) 279- 283

9. P. LOAHARANU, Irradiation foods, $5^{\text {th }}$ ed. American Council on Science and health (2003)

10. U. SURIAWIRIA, Pengantar Mikrobiologi Umum, Penerbit Angkasa, Bandung (1986)

11. HARSOJO, SAINTEKS, XIV (1) (1996) 12-19

12. S. FARDIAZ, dan B.S.L. JENIE, "Masalah Keamanan Pangan Dalam Hubungannya Dengan Mikrobiologi Veterinari. Mikrobiologi di Indonesia". Perhimpunan Mikrobiologi Indonesia (1983) 306-309

13. F.G. WINARNO, Apakah produk pangan di Amerika Serikat "Paling aman"?, Harian KOMPAS, 11 Maret (2003) 30

14. D.H. RATIH, "Keracunan pangan tidak hanya sebabkan diare", harian Kompas 15 Desember (2002) 32.

15. SRI POERNOMO, "Salmonella Pada Ayam Di rumah Potong dan Lingkungannya Di Wilayah Jakarta dan sekitarnya", Seminar Nasional Teknologi Veteriner untuk Meningkatkan Kesehatan Hewan dan Pengamanan Bahan Pangan Asal Ternak, Balitvet, Cisarua, Bogor (1994) 338-345

16. R.D. HARIYADI, "Keracunan pangan tak hanya sebabkan diare". Harian KOMPAS 15 Desember (2002) 32 
17. R.A. SPARRINGA, "Investigasi Kejadian Luar Biasa (KLB) Keracunan Pangan di Indonesia: Masalah dan Saran Pemecahannya", dibawakan pada Pertemuan IImiah Tahunan Perhimpunan Mikrobiologi Indonesia (2003)

18. W.P. RAHAYU, "Kebijakan keamanan pangan", dibawakan pada Seminar dan Diskusi IImiah: Mutu \& Keamanan Pangan, IPB, Bogor (2004)

19. B.S.L. JENIE, "Keamanan pangan", dibawakan pada Seminar dan Diskusi IImiah: Mutu \& Keamanan Pangan, IPB, Bogor, 11 Juni (2004)

20. SRI POERNOMO, "Standar higiene dan keamanan pangan". Bahan Penataran Manajemen Usaha Jasa Boga. IPB-Bogor (1995)

21. S. FARDIAZ, Mikrobiologi Pangan, Gramedia Pustaka Utama, Jakarta (1992)

22. HARSOJO, L. ANDINI dan T.T ROSITA, "Dekontaminasi Bakteri Patogen Pada Daging dan Jeroan Kambing Dengan Iradiasi Gamma", Prosiding Seminar Nasional Teknologi Peternakan dan Veteriner, Bogor (2005) 1027-1031 